\title{
Over aangebracht vermogen en de balans tussen de belangen van de schuldeisers en de andere echtgenoot in het huwelijksvermogensrecht
}

\author{
Een Caribisch huwelijksvermogensrechtelijk onderzoek onder \\ (kandidaat-)notarissen
}

Prof. mr. dr. F.W.J.M. Schols ${ }^{*}$

\section{Het onderzoek}

Op 1 januari 2012 werd Curaçao verblijd met een nieuw huwelijksvermogensrecht. Sint Maarten op 1 april 2014. Curaçao en Sint Maarten ontlenen hiermee het huwelijksvermogensrecht aan Nederland, maar tonen een duidelijk eigen karakter door 'gift en erfrecht' van de gemeenschap van goederen uit te sluiten. In Nederland is, zoals bekend, in eerste instantie een voorstel op dit vlak jammerlijk gesneuveld, maar er werd revanche genomen. ${ }^{1}$ Immers, per 1 januari 2018 is het Nederlandse basisstelsel alsnog gewijzigd: giften en erfrechtelijke verkrijgingen blijven nu ook in Nederland buiten de wettelijke gemeenschap. ${ }^{2}$ Nederland sluit hiermee weer aan bij Curaçao en Sint Maarten. Maar in Nederland is een volgende stap gezet: aangebrachte goederen en schulden blijven in beginsel ook buiten de gemeenschap en de verhaalsmogelijkheden van schuldeisers worden beperkt. Zie hierna in paragraaf 2. Bij de aanvaarding van het ambt van buitengewoon hoogleraar familie(vermogens)recht en erfrecht aan de University of Curaçao besteedde ik onder meer aandacht aan de vraag of Curaçao Nederland op het huwelijksvermogensrechtelijke vlak zou moeten volgen en weer aansluiting zou moeten zoeken bij Nederland. ${ }^{3}$ Met mijn oratie en de publicatie van onderdelen daarvan en deze bijdrage, hoop ik een steentje bij te dragen aan de besluitvorming. Wat echt telt, is vanzelfsprekend de visie van het Caribische notariaat op dit huwelijksvermogensrechtelijke dossier. Vandaar dat ik aan de (kan-

* $\quad$ Prof. mr. dr. F.W.J.M. Schols is hoogleraar privaatrecht, in het bijzonder notarieel recht, bij het Centrum voor Notarieel Recht van de Faculteit der Rechtsgeleerdheid van de Radboud Universiteit Nijmegen. Tevens is hij buitengewoon hoogleraar familie(vermogens)recht en erfrecht aan de Faculteit der Rechtsgeleerdheid van de University of Curaçao en vennoot bij ScholsBurgerhartSchols.

1 Kamerstukken II 2007/08, 28867, 14.

2 Stb. 2017, 177.

3 Mijn oratie draagt de titel Het huwelijksvermogensrecht en erfrecht: een schuldeiserswalhalla?! Een tweeluik over schuldeiseres, boedelmenging en saisine. 
didaat-)notarissen een aantal vragen heb voorgelegd. ${ }^{4}$ In deze bijdrage doe ik verslag van dit onderzoek. ${ }^{5}$

Het onderzoek ziet per saldo op het volgende:

1 De omvang van de gemeenschap: is het volgens het notariaat gewenst de omvang van de gemeenschap nader te beperken en geeft de huwelijksevoorwaardenpraktijk hiervoor aanknopingspunten?

2 De positie van schuldeisers: is er draagvlak onder de (kandidaat-)notarissen om de positie van schuldeisers huwelijksvermogensrechtelijk in te perken?

Vooraf eerst in het kort hetgeen in Nederland is gewijzigd, waarbij de nadruk zal liggen op die facetten die van belang zijn voor het onderhavige verslag.

\section{De Nederlandse wijzigingen per 1 januari 2018}

De wijzigingen die in Nederland per 1 januari 2018 zijn ingevoerd, kan men groeperen in de onderdelen 'omvang van de gemeenschap' en 'schuldeisers'.

\subsection{Omvang van de gemeenschap}

Aangebrachte goederen en schulden blijven in beginsel buiten de gemeenschap van goederen. Dit leest men voor de goederen in artikel 1:94 lid 2 aanhef Nederlands BW (hierna: NBW):

'De gemeenschap omvat, wat haar baten betreft, alle goederen die reeds vóór de aanvang van de gemeenschap aan de echtgenoten gezamenlijk toebehoorden, en alle overige goederen van de echtgenoten, door ieder van hen afzonderlijk of door hen tezamen vanaf de aanvang van de gemeenschap tot haar ontbinding verkregen, met uitzondering van $[\ldots]$ [cursivering; FS].'

4 De enquête had ook een erfrechtelijk onderdeel betreffende de positie van schuldeisers in het erfrecht. Dat onderdeel laat ik buiten beschouwing.

5 Op het moment dat het onderzoek online werd uitgezet, had de stemming in Nederland over het wetsvoorstel in de Eerste Kamer nog niet plaatsgevonden. Het onderzoek werd verricht onder de leden van de Antilliaanse en Arubaanse Notariële Vereniging. De vereniging telt 47 leden. Ik ontving 25 bruikbare formulieren retour. Een deel van de formulieren (15) werden online ingevuld. Een ander deel (10) werd handmatig ingevuld tijdens de Algemene ledenvergadering van de Notariële Vereniging op 27 mei 2017 op Aruba en later digitaal verwerkt. De schriftelijke enquêtes zijn niet ingevuld door de leden die al online hadden deelgenomen aan het onderzoek. Toen de schriftelijke enquêtes werden ingevuld was ook in de Eerste Kamer het wetsvoorstel aangenomen. Alle gestelde huwelijksvermogensrechtelijke vragen worden hierna opgenomen in de bijdrage. Ik dank Netwerk Notarissen en mr. M.E. Ricardo van de University of Curaçao voor de ondersteuning.

6 Zoals men ziet spreekt de wet over goederen 'vanaf de aanvang van de gemeenschap'. Dat is vanzelfsprekend ruimer dan 'ten huwelijk aangebrachte goederen'. Toch spreek ik van aangebrachte goederen en schulden. 
Voor de schulden vindt men dit in artikel 1:94 lid 7 NBW. ${ }^{7}$

De boedelmenging en de absorberende werking van de gemeenschap wordt derhalve beperkt. Niet alleen aangebrachte goederen en schulden blijven buiten de gemeenschap, maar ook verkrijgingen 'krachtens gift en erfrecht' (art. 1:94 lid 2 onder a en c NBW). Dit laatste is op Curaçao en Sint Maarten, zoals gezegd, reeds lang het geval. Dit geldt ook voor de 'insluitingsclausule' van artikel 1:94 lid 3 onder b NBW. Een op genoemde eilanden reeds bekend fenomeen waarmee erflaters en schenkers kunnen bepalen dat de verkrijging toch tot de gemeenschap zal behoren.

Omdat dit nieuwe basisregime tot gevolg kan hebben dat een onderneming en de aandelen van de 'directeur-grootaandeelhouder' (vaker) buiten de gemeenschap vallen, is in artikel 1:95a NBW een vergoedingsregeling opgenomen waarmee de gemeenschap gecompenseerd wordt voor de kennis, vaardigheden en arbeid die een echtgenoot ten behoeve van die buiten de gemeenschap vallende onderneming heeft aangewend. ${ }^{8}$

\subsection{Schuldeisers}

De, ook op Curaçao en Sint Maarten bekende, hoofdregel in artikel 1:96 lid 1 (N)BW dat voor een schuld van een echtgenoot zowel de goederen van de gemeenschap als de eigen goederen kunnen worden uitgewonnen, ongeacht of sprake is van een gemeenschapsschuld of privéschuld, blijft in Nederland van toepassing. Maar het verhaal van een privéschuldeiser is in Nederland per 1 januari 2018 beperkt tot de helft van de opbrengst van een uitgewonnen gemeenschapsgoed. Artikel 1:96 lid 3 NBW luidt als volgt:

'3. Het verhaal op de goederen van de gemeenschap voor een niet tot de gemeenschap behorende schuld van een echtgenoot is beperkt tot de helft van de opbrengst van het uitgewonnen goed. De andere helft komt de andere echtgenoot toe en valt voortaan buiten de gemeenschap. De andere echtgenoot is bevoegd, indien een schuldeiser verhaal op een goed van de gemeenschap zoekt ter zake van een niet tot de gemeenschap

7 Overigens worden, zoals men in het aangehaalde gedeelte van art. 1:94 NBW kan lezen, 'aangebrachte gemeenschappelijke goederen' wel de gemeenschap ingezogen. Dit geldt ook voor de 'aangebrachte gemeenschappelijke schulden', zoals nader omschreven in art. 1:94 lid 7 aanhef NBW. Dit maakt het nieuwe stelsel ondoorzichtig. Zie F.W.J.M. Schols, Over het nieuwe relatievermogensrechtelijke basisstelsel, averij, spoken, gemiste en nieuwe kansen (UCERF-reeks nr. 12). Nijmegen: Ars Aequi 2018.

8 Art. 1:95a NBW luidt als volgt: 'Indien een onderneming buiten de gemeenschap valt, komt ten bate van de gemeenschap een redelijke vergoeding voor de kennis, vaardigheden en arbeid die een echtgenoot ten behoeve van die onderneming heeft aangewend, voor zover een dergelijke vergoeding niet al op andere wijze ten bate van beide echtgenoten komt of is gekomen. 2. Ook indien een onderneming op naam en voor rekening van een personenvennootschap of een rechtspersoon wordt uitgeoefend, de gerechtigdheid tot die personenvennootschap of die rechtspersoon buiten de gemeenschap valt en de echtgenoot die daartoe is gerechtigd, in overwegende mate bij machte is te bepalen dat de winsten van die onderneming hem rechtstreeks of middellijk ten goede komen, komt ten bate van de gemeenschap een redelijke vergoeding voor de kennis, vaardigheden en arbeid die een echtgenoot ten behoeve van die onderneming heeft aangewend, voor zover een dergelijke vergoeding niet al op andere wijze ten bate van beide echtgenoten komt of is gekomen.' Ik laat ook art. 1:95a NBW in deze bijdrage rusten. Ik verwijs voor mijn bevindingen naar F.W.J.M. Schols, 'Over MKB-relatievermogensrecht, de achilleshiel en (ijskoude) MKB-voorwaarden met zweet en tranen', WPNR 2016/7120. Zie ook M.J.A. van Mourik \& F.W.J.M. Schols, Huwelijksvermogensrecht (Monografieën Privaatrecht, nr. 46.2), Deventer: Kluwer 2017. 
behorende schuld, het goed waarop de schuldeiser verhaal zoekt, over te nemen tegen betaling van de helft van de waarde van dat goed uit zijn eigen vermogen. Vanaf het tijdstip van de overneming is dit een eigen goed van deze echtgenoot, dat niet in de gemeenschap valt.'

$\mathrm{Nu}$ aangebrachte schulden in Nederland, zoals gezegd, in beginsel privéschulden zijn, wordt de categorie privéschulden groter, met als gevolg een vergroting van de impact van dit artikel 1:96 lid 3 NBW.

Op schuldeisersvlak is in Nederland nog een aantal wijzigingen doorgevoerd. Om de uitwinningsmogelijkheid en de draagplicht zo veel mogelijk in balans te brengen, is de aanwijsbevoegdheid van artikel 1:96 lid 2 NBW uitgebreid naar gemeenschapsschulden:

'Voor een in de gemeenschap gevallen schuld van een echtgenoot kunnen de eigen goederen van deze echtgenoot niet worden uitgewonnen, indien hij goederen van de gemeenschap aanwijst, die voldoende verhaal bieden.'

Een dergelijke regel geldt op Curaçao en Sint Maarten in artikel 1:96 lid 2 BW slechts voor privéschulden. Het venijnige artikel 61 Faillissementswet, ${ }^{9}$ op Curaçao en Sint Maarten artikel 57 Faillissementsbesluit 1931 en op Aruba artikel 57 Faillissementsverordening, wordt teruggesnoeid tot één lid waarin is bepaald dat de echtgenoot van de schuldenaar alle goederen die hem toebehoren en die niet in de huwelijksgemeenschap vallen, terugneemt. Die goederen vallen derhalve niet in het faillissement van de schuldenaar.

Intern tussen de echtgenoten brengt artikel 1:100 lid 2 NBW een kleine wijziging op het vlak van de draagplicht indien de gemeenschap onder water staat en uit de eisen van redelijkheid en billijkheid, mede in verband met de aard van de schulden, een andere draagplicht dan voor gelijke delen voortvloeit.

\section{Het onderzoek}

$\mathrm{Nu}$ naar de gestelde vragen en de bevindingen van de (kandidaat-)notarissen.

3.1 Onderdeel 'omvang van de gemeenschap'

Vraag: Adviseert u uw cliënten (aanstaande echtgenoten) om in de wettelijke gemeenschap van goederen te trouwen?

9 Zie voor een overzicht van de rechtspraak F.A. van Lith, 'Huwelijksvermogensrecht en faillissementsrecht: and never the twain shall meet?', FTV 2014, afl. 5. 
Figuur 1

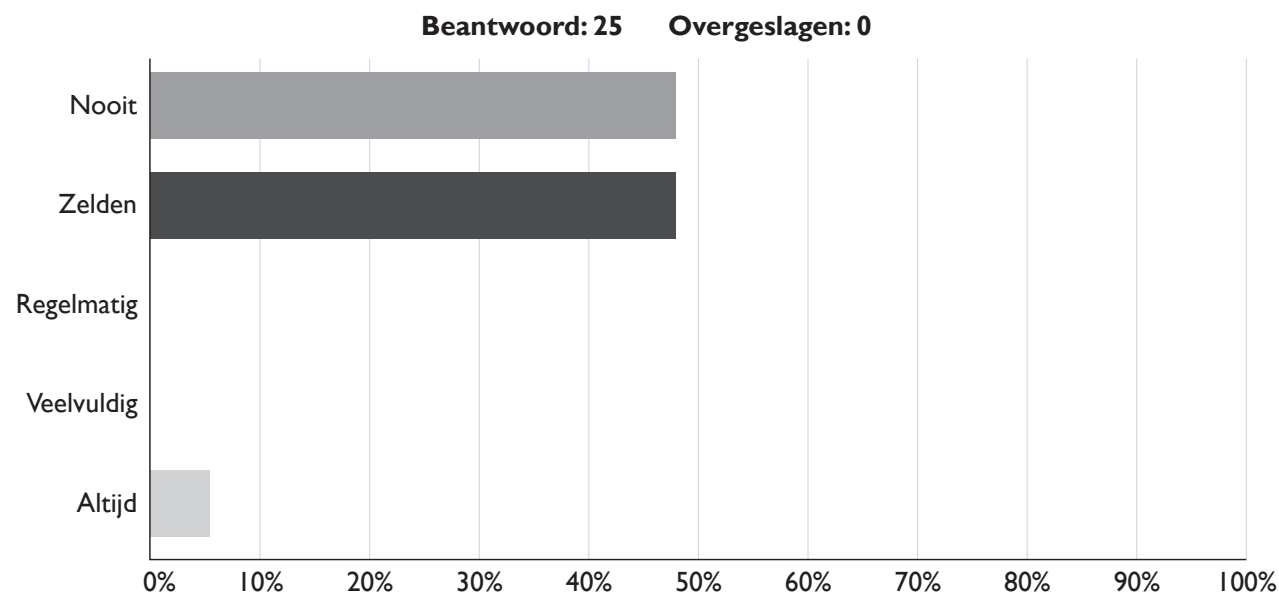

Blijkbaar is de wettelijke gemeenschap van goederen wel populair bij de huwende bevolking, die massaal zonder het maken van huwelijkse voorwaarden trouwt, ${ }^{10}$ maar niet bij de notariële adviseur (zie figuur 1). Dat zet aan het denken. De vraag komt dan op waarom men het basissysteem niet vaker adviseert. Dat was ook de volgende vraag in het onderzoek.

Vraag: Waarom adviseert $u$ het basisstelsel niet vaker?

\section{Tabel 1}

\begin{tabular}{llc}
\hline Antwoordkeuzen & Reacties \\
\hline De verhaalsmogelijkheden van crediteuren zijn te riant. & $40,91 \%$ & 9 \\
$\begin{array}{l}\text { De lotsverbondenheid strekt niet zo ver dat ook voorhuwelijkse goederen } \\
\text { en schulden gedeeld moeten worden }\end{array}$ & $72,73 \%$ & 16 \\
Anders, namelijk: & $22,73 \%$ & 5 \\
Totale aantal respondenten: 22 & & \\
\hline
\end{tabular}

Van de standaardantwoorden (men mocht meerdere antwoorden aanvinken) scoort het antwoord dat de lotsverbondenheid niet zo ver strekt dat ook voorhuwelijkse goederen en schulden gedeeld moeten worden het hoogst (zie tabel 1). Aanbreng wenst men, bezien door de bril van de adviseur, blijkbaar niet te delen. Maar ook de te riante positie van de schuldeisers, waarbij dan met name gedacht moet worden aan artikel 1:96 lid $1 \mathrm{BW}$, scoort hier als antwoord hoog. Onder de post 'Anders, namelijk' werd (geparafraseerd) opgemerkt dat Aruba te veel echtscheidingen kent en ook dat het automatisme van boedel-

10 J. Debrot-Steegstra, 'De praktijk en de rechtsontwikkeling van de huwelijkse voorwaarden op Curaçao over de jaren 1975 tot en met 1999', TAR Justicia 2002, afl. 4 en 2003, afl. 1. Slechts ongeveer 15\% van de gehuwden maakte in de periode 1995-1999 huwelijkse voorwaarden. Uit - nog niet gepubliceerd - onderzoek van mr. C. Jenkin blijkt dat het aantal huwelijken op huwelijkse voorwaarden is toegenomen. In de periode 2012-2016 trouwde ruim 18\% op huwelijkse voorwaarden. 
menging betreffende goederen en schulden te ver gaat. Bovendien wordt genoteerd dat echtgenoten vaak in een vergelijkbare financiële positie verkeren en een gemeenschap van goederen bij een echtscheiding tot problemen leidt en men dan kiest voor een minder gecompliceerd stelsel. Zeer relativerend is de opmerking van een (kandidaat-)notaris dat de privéomstandigheden van cliënten geen aanleiding hebben gegeven om te kiezen voor de gemeenschap van goederen, hetgeen ook ligt aan het type cliënt dat advies komt vragen.

Nieuwsgierig ben ik natuurlijk naar de mening van die ene (kandidaat-)notaris die het basisstelsel wel altijd adviseert.

\section{Vraag: Waarom adviseert $u$ het basisstelsel?}

De betreffende (kandidaat-)notaris geeft aan (als een van de standaardantwoorden) dat het feit dat de verhaalsmogelijkheden van crediteuren riant zijn, bij de lotsverbondenheid past. Blijkbaar is de positie van schuldeisers voor hem of haar geen reden om aan het basisstelsel voorbij te gaan. ${ }^{11,12}$

De volgende vragen zien op de aangebrachte goederen en schulden.

Vraag: Kiezen uw cliënten indien zij huwelijkse voorwaarden maken ervoor om aangebracht vermogen (activa en passiva) te delen bij scheiding?

Deze vraag houdt vanzelfsprekend rechtstreeks verband met de regel die in Nederland geldt per 1 januari 2018 dat aangebracht vermogen in beginsel buiten de huwelijksgemeenschap blijft.

De cijfers in figuur 2 spreken boekdelen. Degenen die huwelijkse voorwaarden maken, zijn in de regel niet geneigd ook aangebracht vermogen te delen bij scheiding. Is dat anders bij het einde van het huwelijk door overlijden?

Vraag: Kiezen uw cliënten indien zij huwelijkse voorwaarden maken ervoor om aangebracht vermogen (activa en passiva) te delen bij overlijden?

Bij overlijden is men vaker geneigd aangebrachte schulden en goederen te delen, zo blijkt uit figuur 3. Dit ligt om diverse redenen in de lijn der verwachting. De postmortale solidariteit is in de regel groter dan in het geval van scheiding. Verzorgings- en fiscale motieven zullen een rol spelen.

11 Voor de volledigheid wijs ik nog op de andere standaardantwoorden (men mocht er meerdere aanvinken) die niet werden gekozen:

- $\quad$ het systeem (alles delen) past goed bij de huwelijkse lotsverbondenheid;

- de eenvoud is groot;

- de meesten hebben geen last van de riante verhaalsmogelijkheden van crediteuren.

En er was ook ruimte voor een 'anders'. Maar ook van die ruimte werd geen gebruik gemaakt.

12 In twee gevallen werd op het papieren formulier de vraag waarom het basisstelsel geadviseerd wordt ook ingevuld door (kandidaat-)notarissen die het basisstelsel zelden adviseren. De volgende antwoorden werden gegeven: 'Anders, namelijk: voorkomen van extra successiebelasting' en 'Soms bij starters als ze alles nog moeten opbouwen. In een dergelijk geval eerder een verrekenbeding om toch tijdens huwelijk bescherming te bieden tegen schuldeisers. U moet rekening houden met het feit dat heel weinig mensen op de eilanden überhaupt huwelijkse voorwaarden maken. Wij zouden beter naar een beperkte gemeenschap kunnen gaan.' 
Figuur 2

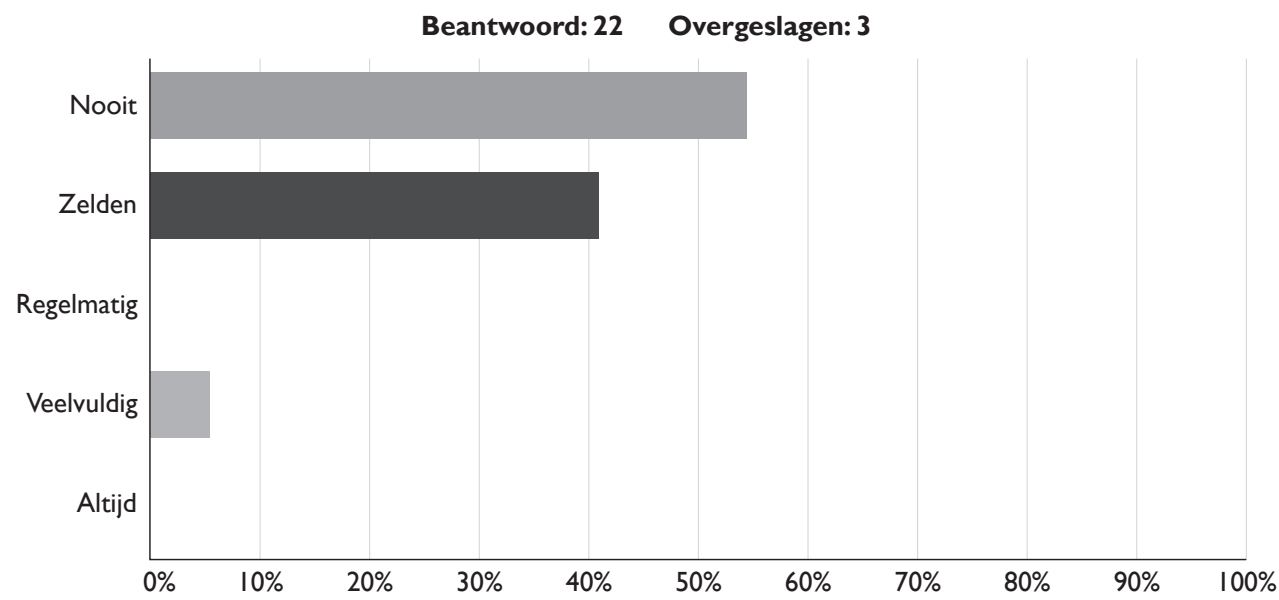

Figuur 3

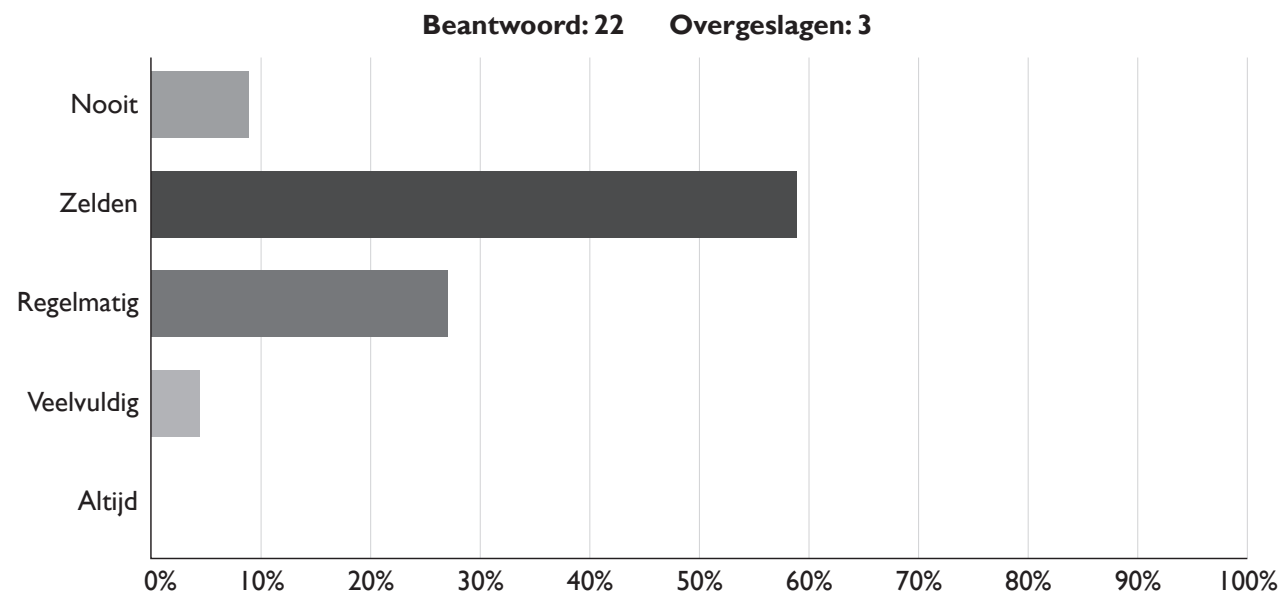

De voorafgaande twee vragen zagen op de wens van de cliënten en de keuzes die gemaakt worden in huwelijkse voorwaarden. Wat is de visie van het Caribische notariaat op de status van aangebracht vermogen en de gemeenschap van goederen? De volgende vraag ziet hier op.

Vraag: Aangebracht vermogen (activa en passiva) dient in de gemeenschap van goederen te vallen.

Het beeld is duidelijk (zie figuur 4). Niemand beantwoordde de vraag met 'ja'. Aanbreng hoort niet in de gemeenschap, zo is de overduidelijke mening van het Caribische notariaat. Velen maakten een belangrijke nuance door het standaardantwoord 'nee, maar' aan te vinken. Deze staat voor: 'Nee, maar er dienen wel bewijsvermoedens te gelden voor het geval er discussie ontstaat tussen echtgenoten over de vraag of iets gemeenschappelijk of privé is.' Een voorziening in dit kader is op Curaçao en Sint Maarten al gegeven met artikel 1:94 


\section{Figuur 4}

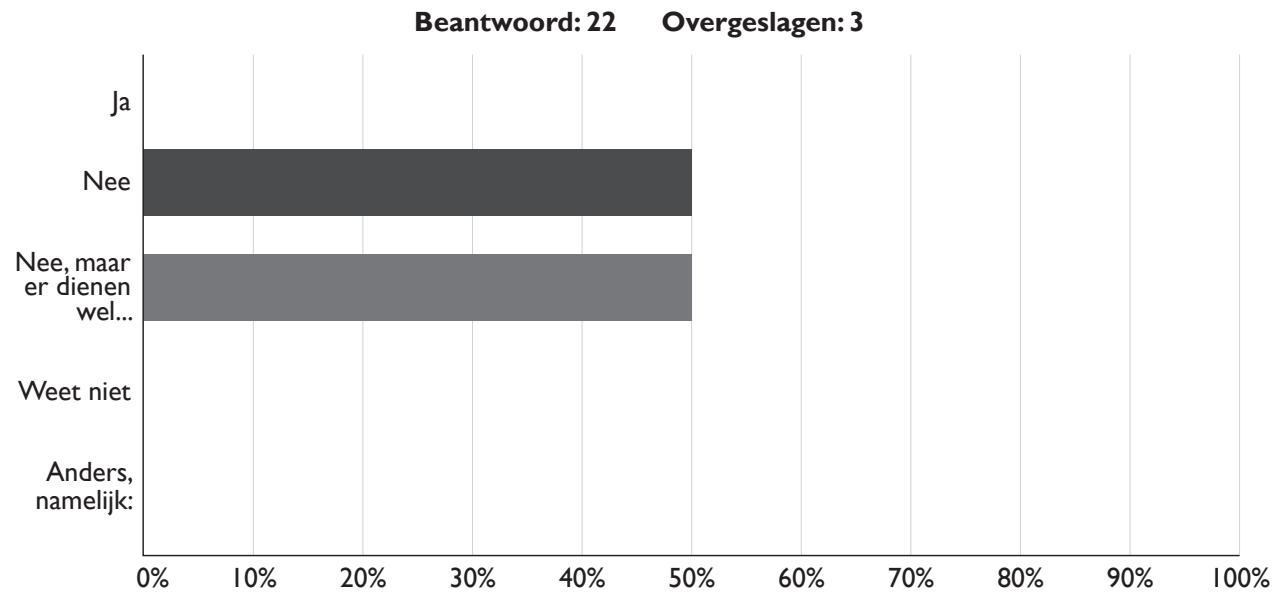

lid 7 BW. Bestaat tussen echtgenoten een geschil aan wie van hen beiden een goed toebehoort en kan geen van beiden zijn recht op dit goed bewijzen, dan wordt dit goed als een gemeenschapsgoed aangemerkt. Met deze regeling lijkt een beperktere gemeenschap zeer wel werkbaar.

Een voorzichtige conclusie op basis van de gepresenteerde cijfers luidt dat wat betreft de omvang van de gemeenschap het notariaat in grote meerderheid voorstander is om deze nader te beperken.

\subsection{Onderdeel 'schuldeisers'}

Niet alleen gemeenschapsschuldeisers hebben verhaal op het huwelijksvermogensrechtelijke gemeenschappelijke vermogen van de echtgenoten, maar ook de privéschuldeisers. Artikel 1:96 lid 1 BW bepaalt immers het volgende:

'Voor een schuld van een echtgenoot kunnen, ongeacht of deze in de gemeenschap is gevallen, zowel de goederen der gemeenschap als zijn eigen goederen worden uitgewonnen.'

Artikel 1:96 lid 3 NBW heeft, zoals gezien, in Nederland per 1 januari 2018 geleid tot een beperking van de verhaalsmogelijkheden voor privéschuldeisers. Dit in combinatie met het kwalificeren van aangebrachte schulden als privéschulden. De volgende vraag ziet op dit nieuwe artikel 1:96 lid 3 NBW.

Vraag: In Nederland is voorgesteld het verhaal van privéschuldeisers te beperken tot per saldo de helft van de gemeenschap van goederen. In Nederland wordt bovendien voorgesteld de categorie privéschulden uit te breiden met aangebrachte schulden. Vindt $u$ dat een goede stap?

Ongeveer 68\% van de (kandidaat-)notarissen vindt dit een goede stap. 27\% van de respondenten evenwel niet (zie figuur 5). 


\section{Figuur 5}

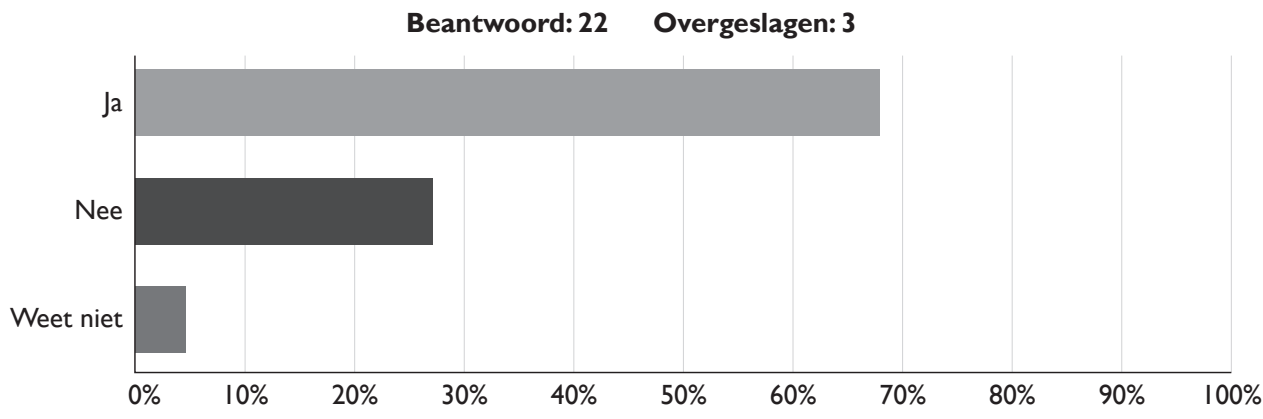

De vraag die ik aan de orde stelde in mijn eerdergenoemde oratie was of de positie van schuldeisers niet nog verder beperkt zou moeten worden. Artikel 1:96 lid 3 NBW ziet immers slechts op privéschuldeisers. Is het voor de hand liggend dat gemeenschapsschuldeisers in alle gevallen verhaal hebben op 'de helft' in de gemeenschap van de 'andere echtgenoot', te weten de echtgenoot die de schuld niet aanging? ${ }^{13}$ Denk aan het geval dat de andere echtgenoot voor het aangaan van de schuld geen toestemming gaf of daardoor niet gebaat is, terwijl de betreffende uit te winnen goederen van de zijde van de andere echtgenoot in de gemeenschap zijn gevloeid. De volgende vraag ziet op het vraagstuk of ook de positie van gemeenschapsschuldeisers niet te royaal is.

Vraag: Vindt $u$ het terecht dat voor een gemeenschapsschuld die door één van de echtgenoten is aangegaan de gehele gemeenschap kan worden uitgewonnen? Derhalve ook de helft van de ander?

$27 \%$ van de (kandidaat-)notarissen lijkt geen reden te zien om iets te doen aan het schuldeisersregime wat betreft de gemeenschapsschuldeisers (zie figuur 6). Opvallend is dat dit percentage hetzelfde is als het percentage bij de vorige vraag. Een vergelijkbaar percentage vond artikel 1:96 lid 3 NBW geen goede stap. ${ }^{14}$

Ruim 68\% zou wel iets willen doen aan de positie van de gemeenschapsschuldeisers in die zin dat de gemeenschapsschuldeisers slechts verhaal moeten kunnen nemen op (per saldo) de helft van de gemeenschap van goederen. Iets meer dan de helft van degenen die iets zien in de beperking van de verhaalsmogelijkheden van gemeenschapsschuldeisers vinkt aan dat er slechts verhaal zou moeten kunnen worden genomen op de gemeenschappelijke goederen/gelden voor zover die van de zijde van de schuldenaar in de gemeenschap zijn gevallen. De goederen/gelden die van de zijde van de andere echtgenoot in de gemeenschap zijn gevallen, dienen buiten schot te blijven. In dit standaardantwoord was aangegeven dat de bewijslast hierbij dan niet ligt op de schuldeiser maar op de echtgenoten. Van de ruimte 'Anders, namelijk' werd geen gebruik gemaakt.

Focussen we nader op de gemeenschapsschulden en de daaraan gekoppelde verhaalsmogelijkheden dan is ook de volgende vraag interessant.

13 Het vraagstuk of aandelen in een wettelijke gemeenschap aanwijsbaar zijn, laat ik thans rusten. Zie onlangs nog HR 3 februari 2017, ECLI:NL:HR:2017:156.

14 De groepen zijn evenwel niet identiek. 
Figuur 6

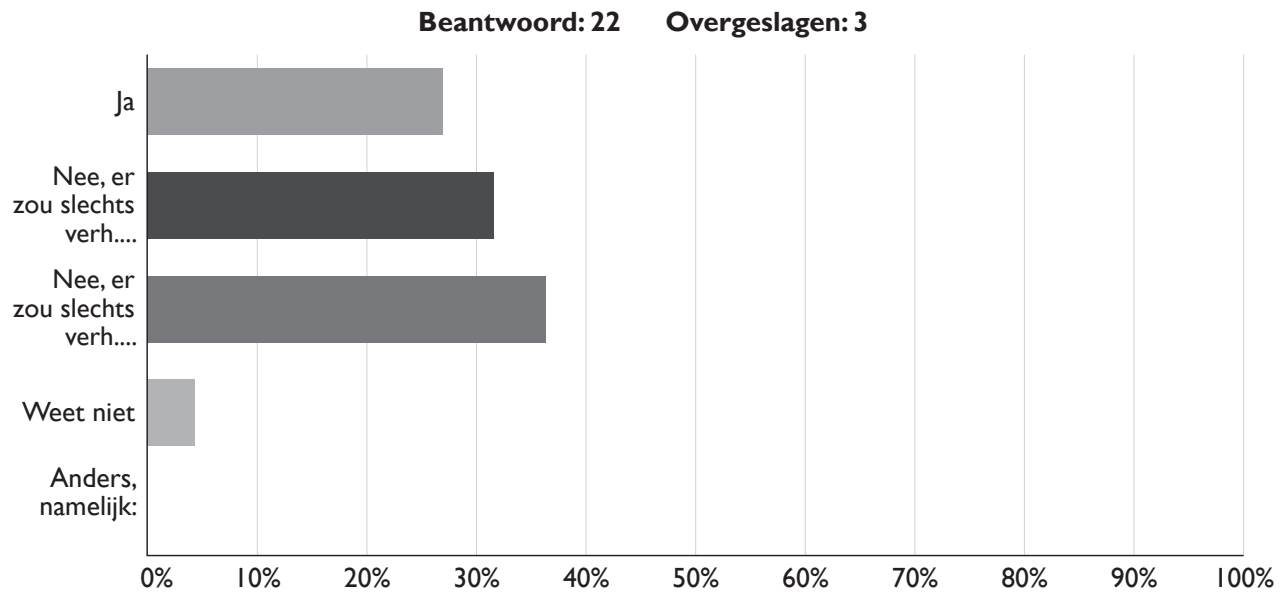

Vraag: Geldleningen zijn, ook al heeft de andere echtgenoot geen weet van het feit dat deze zijn aangegaan, in beginsel gemeenschapsschulden en verhaalbaar op de gemeenschap.

Ter bescherming van de andere echtgenoot zou het volgende kunnen worden voorgesteld:

$\mathrm{i}$ Onder het toestemmingsartikel 1:88 BW moet ook het aangaan van omvangrijke, nader te omschrijven, geldleningen ('significant loans') vallen, zodat in geval van het ontbreken van toestemming de lening door de andere echtgenoot vernietigbaar is.

ii Schulden uit omvangrijke, nader te omschrijven, geldleningen ('significant loans'), zonder toestemming van de andere echtgenoot, dienen als privéschuld te worden aangemerkt en slechts verhaalbaar te zijn op de helft van de gemeenschap van goederen.

Bent $u$ het eens met een van deze twee voorstellen?

De vragen spreken voor zich in die zin dat beide voorstellen de andere echtgenoot extra beschermen. Voorstel I breidt de bescherming uit via de toestemmingsbepaling van artikel 1:88 BW. Dat zou betekenen dat ook voor niet in het basisstelsel gehuwde echtgenoten deze extra bescherming zou gelden. Dat kan voor de een misschien onaanvaardbaar zijn omdat de regeling van artikel 1:88 BW dwingendrechtelijk van aard is, terwijl men wellicht denkt in termen van 'partijautonomie'. De ander ziet hier wellicht een mooie beschermingsbijvangst. Over smaak valt niet te twisten. Voorstel II is gekoppeld aan het basisstelsel als zodanig, en derhalve van regelend recht (art. 1:93 BW) en biedt bescherming aan de ander door de verhaalsmogelijkheden te beperken tot de helft van de huwelijksgemeenschap indien de toestemming van de ander ontbreekt. Welk voorstel verdient volgens het Caribische notariaat de voorkeur? Of ziet men er niets in?

Zie figuur 7 voor de gegeven antwoorden. Velen zijn blijkbaar toch bereid om het huidige systeem te wijzigen. Blijkbaar zelfs degenen die het nieuwe artikel 1:96 lid 3 NBW geen goede stap vinden en het terecht vinden dat voor een gemeenschapsschuld die door één van de echtgenoten is aangegaan de gehele gemeenschap kan worden uitgewonnen. Zie de vorige twee vragen. Dit hoeft zich niet per se te bijten. De genoemde voorstellen zijn concreet en beperkt(er). 43\% van de (kandidaat-)notarissen opteert voor voorstel I. De meesten, te weten $57 \%$, kiezen voor voorstel II. 
Figuur 7

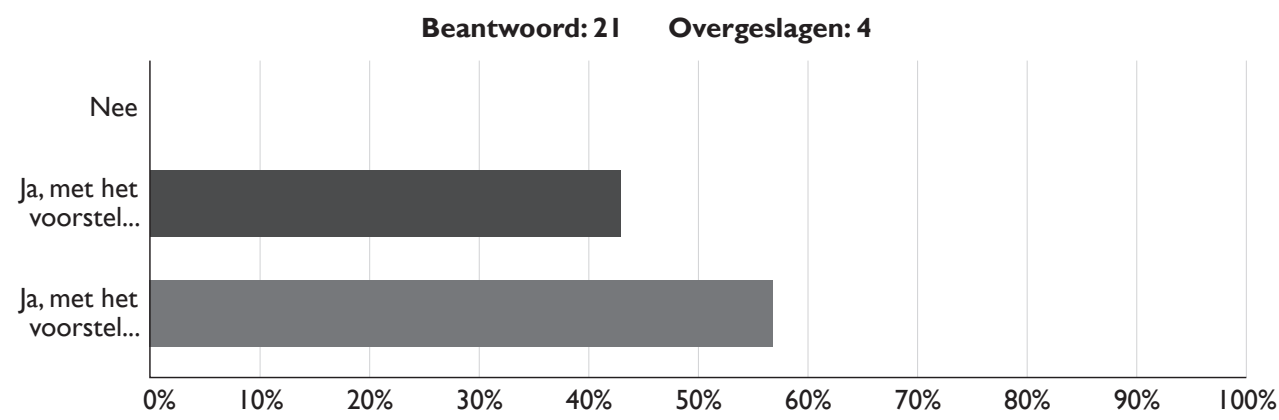

Figuur 8

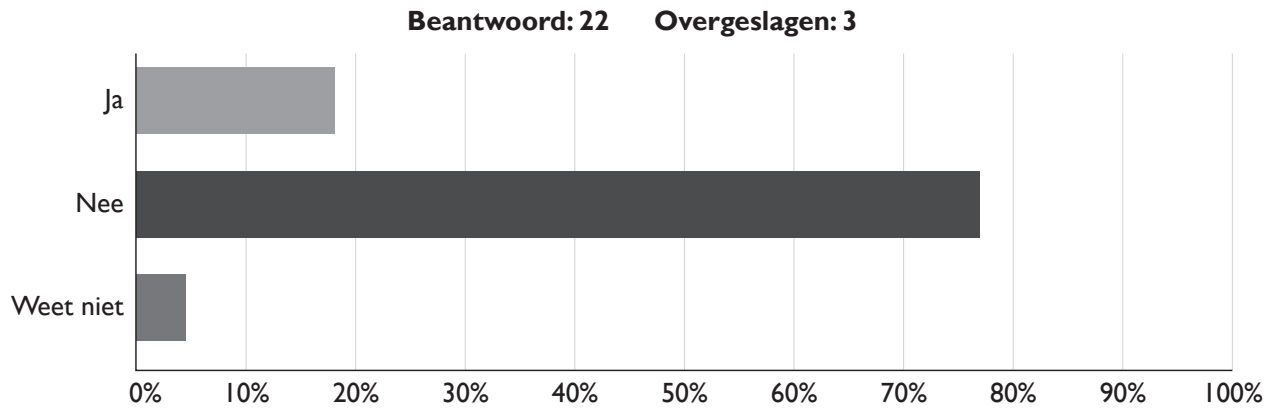

Tot slot nog het volgende. In Nederland is, mijns inziens ten onrechte, niets gedaan met artikel 1:85 BW dat ook op Aruba, Curaçao en Sint Maarten bestaat. De laatste vraag die ik in dit verslag aan de orde wil stellen, ziet hier op.

Vraag: In artikel 1:85 BW is bepaald dat de ene echtgenoot naast de andere echtgenoot aansprakelijk is voor de door deze ten behoeve van de gewone gang van de kosten van de huishouding aangegane verbintenissen. Dit betekent dat de schuldeiser zich niet alleen kan verhalen op de gemeenschap maar ook op het privévermogen (bijvoorbeeld geërfd vermogen) van de echtgenoot die deze schuld niet aanging.

Vindt $u$ deze bepaling wenselijk?

$18 \%$ van de (kandidaat-)notarissen vindt deze bepaling wenselijk (zie figuur 8). Drie respondenten omdat de bepaling past bij de lotsverbondenheid tussen echtgenoten, één respondent omdat het de ondernemer beschermt die handelt in huishoudelijke goederen en een andere respondent omdat de bepaling de echtgenoten beschermt in die zin dat men makkelijker huishoudelijke goederen blijft leveren aan het gezin. Het betreffen standaardantwoorden. ${ }^{15}$

77\% vindt de bepaling onwenselijk. Waarom? Meerdere standaardantwoorden konden worden aangevinkt. Tien respondenten waren van mening dat het artikel niet meer past bij de huidige tijdsgeest. Een vergelijkbaar aantal ziet geen reden om schuldeisers te faciliteren 
als ze zaken doen met iemand die toevallig gehuwd is. Vier (kandidaat-)notarissen zagen een niet te rechtvaardigen verschil met samenwoners. ${ }^{16}$

Op het onderdeel 'schuldeisers' kan de, wederom voorzichtige, conclusie getrokken worden dat er draagvlak lijkt te zijn in het notariaat om de positie van schuldeisers in het onderhavige huwelijksvermogensrechtelijke kader enigszins in te perken.

\section{Concluderend}

Ik ken veel gewicht toe aan de huwelijksvermogensrechtelijke mening van het Caribische notariaat. Dit eenvoudige onderzoek geeft in ieder geval de sfeer rondom de thema's 'omvang van de gemeenschap' en 'schuldeisers' goed weer. Het notariaat is in grote meerderheid voorstander om de omvang van de gemeenschap nader te beperken en aangebrachte goederen en schulden buiten de gemeenschap te houden. Ook ik kan me in een nadere beperking van de gemeenschap van goederen goed vinden. ${ }^{17}$ De uitkomsten van dit onderzoek geven mij ook steun in mijn gedachten dat het beter kan wat betreft de wettelijke balans tussen de belangen van de schuldeisers en de andere echtgenoot. 